\title{
NATURA BEZPIECZEŃSTWA I PORZĄDKU PUBLICZNEGO
}

\section{Streszczenie:}

W artykule przedstawiono rozważania dotyczące zagadnień związanych z materialnym i subiektywnym zakresem bezpieczeństwa publicznego i porządku publicznego. Prezentowane obrady mają charakter teoretyczny i odzwierciedlają głównie poglądy polskich naukowców, w szczególności ze sfery nauk prawnych i nauk o bezpieczeństwie. Przedstawione w artykule refleksje dowodzą, że wyjaśnienia istoty obu pojęć, które znajdują się w sferze zainteresowań autora, ewoluowały. Początkowo stanowiły one podstawową wartość w koncepcjach kształtowania się społeczeństw i państw, ale obecnie są postrzegane i definiowane na różne sposoby, w zależności od dziedziny, której dotyczą.

Wyniki przeprowadzonych badań wskazują, że brak bezpieczeństwa publicznego lub jego zakłócenie implikuje brak możliwości jego rozwoju i stymuluje do działania, co czasami dla jednostki lub innych podmiotów niekoniecznie oznacza rozwój. Działania te mogą czasami być ryzykowne dla istnienia osoby, ponieważ potrzeba rozwoju jest silniejsza niż potrzeba istnienia. Brak bezpieczeństwa i możliwości awansu może nawet doprowadzić jednostkę do samozniszczenia lub do szukania substytutów bezpieczeństwa, aby się rozwijać. Interesujące jest to, że porządek publiczny był determinowany zarówno przez państwo, które kształtowało prawo, jak i inne społecznie akceptowane normy (moralne, kulturowe, etyczne, religijne lub zwyczaje). Z drugiej strony, treść tego pojęcia również podlegała zmianom, ze względu na zmieniające się standardy zachowania danej społeczności, zmiany panujących warunków życia, a także zmieniające się poglądy, normy prawne i nielegalne.

Przeprowadzone badania dowodzą, że w dzisiejszym świecie nauki nie ma powszechnie przyjętej definicji bezpieczeństwa i porządku publicznego. Pomimo zdecydowanie występujących różnic interpretacyjnych wynikających z przynależności do konkretnych dyscyplin naukowych, można również zauważyć zagadnienia, które łączą te pojęcia. Są one przedmiotem ochrony i środowiska, w którym działa. $Z$ badań wynika również, że właściwa interpretacja pojęć bezpieczeństwa publicznego i porządku publicznego jest gwarancją niezagrożonego funkcjonowania człowieka, przetrwania w dynamicznie zmieniającym się otoczeniu, tworzenia wizji przyszłości i jej przekształcania w warunki sprzyjające rozwojowi.

Zakończone badania pozwalają przyjąć, że bezpieczeństwo publiczne i porządek publiczny są pożądanym procesem zdefiniowanym przez prawo, umożliwiającym niezakłócone funkcjonowanie człowieka, grup społecznych, organizacji i instytucji państwowych. Instytucje, jednostki, grupy społeczne w państwie.

Slowa kluczowe: zagrożenie, bezpieczeństwo, bezpieczeństwo publiczne, porządek publiczny, prawo, organizacja.

\section{Анна Тичковська - Коверчик Головне Управління обласної поліції у Врочлаві, Польщза}

\section{ХАРАКТЕРИСТИКА БЕЗПЕКИ І ГРОМАДСЬКОГО ПОРЯДКУ}

Анотація: У статті представлені міркування щодо питань, пов'язаних із матеріальною та суб'єктивною сферою громадської безпеки та громадського порядку. Представлені міркування носять теоретичний характер і відображають переважно погляди Польських науковців, зокрема у сфері правових наук та наук про безпеку. Роздуми, наведені в цій роботі, доводять, що пояснення сутності обох понять, що входять до сфери інтересів автора, еволюціонували. Спочатку вони становили базову цінність у концепціях формування суспільств і держав, але сьогодні вони сприймаються і визначаються по-різному, залежно від сфери, до якої вони належать.

Результати проведеного дослідження свідчать про те, що відсутність почуття громадської безпеки або ії порушення означає відсутність можливостей для ії розвитку та стимулює дії, що іноді для окремої особи чи інших суб'єктів не обов'язково означає розвиток. Ці дії іноді можуть бути ризикованими для існування людини, оскільки потреба розвиватися сильніша за потребу існувати. Відсутність безпеки та можливостей для просування може навіть привести людину до самознищення або пошуку заміни безпеки, щоб процвітати. Цікаво, що громадський порядок був встановлений як державою, яка формувала право, так і іншими суспільно визнаними нормами (моральними, культурними, етичними, релігійними чи звичаями). 3 іншого боку, зміст цього поняття також піддавався 
змінам через зміну стандартів поведінки певної громади, зміни умов життя, що склалися, а також зміни поглядів, правових і неправових норм.

Проведене дослідження доводить, що сьогодні у світі науки не існує загальноприйнятого визначення безпеки та громадського порядку. Незважаючи на певні інтерпретаційні відмінності, що виникають через належність до конкретних наукових дисциплін, можна помітити й проблеми, які об'єднують ці терміни. Вони є об'єктами охорони та середовищем, в якому вона діє. Дослідження також показує, що правильне тлумачення понять громадської безпеки та громадського порядку є запорукою безперешкодного функціонування людини, виживання в динамічно-мінливому середовищі, формування бачення майбутнього та їх перетворення в умови для розвитку.

Проведене дослідження дозволяє припустити, що громадська безпека та громадський порядок є бажаним процесом, визначеним законом, який забезпечує безперебійне функціонування людини, соціальних груп, організацій та державних інституцій. Державні установи, особи, соціальні групи в державі.

Ключові слова: загроза, безпека, громадська безпека, громадський порядок, людина, право, організація.

\title{
Anna Tychkovska - Koverchyk Main Headquarters of the Regional Police in Wroclaw, Poland
}

\section{CHARACTERISTICS OF SECURITY AND PUBLIC SAFETY}

\begin{abstract}
The article presents considerations relating to issues associated with the material and subjective scope of public security and public order. Presented deliberations are theoretical in nature and reflect mainly the views of Polish scientists, in particular from the sphere of legal and security sciences. The reflections presented in this paper prove that the explanations of the essence of both concepts, which are in the sphere of the author's interest, have evolved. Initially, they constituted a basic value in the concepts of formation of societies and states, but nowadays they are perceived and defined in different ways, depending on the field to which they pertain.

The results of the conducted research indicate that the lack of a sense of public security or its disruption implies the absence of opportunities for its development and stimulates action, which sometimes for an individual or other entity does not necessarily mean development. These actions can sometimes be risky for the existence of the person because the need to develop is stronger than the need to exist. The lack of security and opportunities for advancement may even lead the individual to self-destruction or to look for substitutes for security to thrive. Interestingly, public order was determined both by the state, which shaped the law, and other socially accepted norms (moral, cultural, ethical, religious or customs). On the other hand, the content of this notion was also subject to change, due to shifting standards of behaviour of a given community, alterations in the prevailing living conditions, as well as changing views, legal and non-legal norms.

The conducted research proves that there is no commonly accepted definition of security and public order in the world of science today. Despite definitely occurring interpretational differences resulting from belonging to specific scientific disciplines, one can also notice the issues that unite these terms. These are the subject of protection and the environment in which it operates. The research also shows that a proper interpretation of the concepts of public safety and public order is a guarantee of unthreatened human functioning, survival in a dynamically changing environment, conceiving visions for the future and their transformation into conditions of development.

The completed research allows us to assume that public safety and public order is a desirable process defined by law that enables undisturbed functioning of a human being, social groups, organisations and state institutions. Institutions, individuals, social groups in the state.
\end{abstract}

Keywords: threat, security, public safety, public order, law, organization.

\section{Introduction}

The introduction to the presented considerations should begin with a question: what is the nature of security and public order? To discover the essence of these concepts it is necessary to explore them through the range of proposed definitions of public safety and public order in the doctrine of security sciences.

What is nature? Encyclopedia PWN defines the concept of nature as the essence, the principle of being of human reality, which is understood differently depending on the concept (...) [1]. On the contrary, Słownik języka polskiego PWN (PWN Dictionary of Polish Language) provides a definition of nature as, among others, a set of features characteristic for certain phenomena, objects [2].
Hence, the question, which was formulated at the beginning, concerns finding the properties, a set of properties, which characterize the public security [3] public order, and thus their essence of being in human reality depending on the concept.

\section{Research methodology}

For the needs of the study, the research problem was formulated in the form of a question: what are the subject scopes of public security and public order?

The question as phrased in this manner required clarification of the basic notions for the subject matter, namely security and order and the adjective public. 
In the research documented in this article, the strategy of qualitative enquiry was applied, which in this case amounted to clarifying the essence of the identification problems of security and public order and critical thinking about the research problem, which was expressed by a multifaceted analytical review of the scientific literature describing the matter [4].

In the research, the results of which are presented in this article, valuable scientific literature from the field of legal and security sciences was used, employing such research methods as: analysis, synthesis, comparison, abstraction, generalization and inference [5].

Due to the author's interests, the studies included in this literature constitute the output of Polish theoreticians.

\section{An attempt at identifying the problem}

The very notion of security [6] is defined in numerous ways [7], therefore, considering it, also in the public dimension, there is no consensus on the recognition of a uniform definition with which all experts on the problem would agree [8]. One thing is certain, all authors who make attempts to define the notions of public safety and public order agree that these ideas are characterised by indeterminacy, which makes it impossible to define these concepts in a clear and precise manner.

According to some authors, public security and public order are two different and equal values, as they determine the undisturbed functioning of the state and its institutions [9]. In such an approach, public security refers to the protection of people, their life, health, property and national assets against unlawful attacks violating these goods, and public order to the assurance of undisturbed, consistent coexistence with accepted legal norms, for members of society [10].

So, we should take a closer look at these terms and their meanings. Let us use, at least to a small extent, already existing definitions developed by recognized authorities in the doctrine of safety related to public safety and public order [11], in order to find their properties (a set of features), which they are characterized by, and thus to discover their impact on the essence of being human in the reality, which they create. For this purpose, we shall make an attempt to analyse already existing, selected definitions of public security and public order [12].

One of them is Franciszek Mroczko. He believes that public safety in its general scope covers broadly understood security of all citizens and is guaranteed by appropriate state institutions. By the term public security he comprehends a state in which there is no threat [13] to the functioning of the state organization and the implementation of its interests. It is a state that enables the development of this organization. From such a definition of public security, it follows that there are no manifestations of any dangers to either the local community or the whole society. In particular, according to Franciszek Mroczka, public security concerns safety in transportation (road, railway, water, air traffic), lack of hazards [14] disasters, natural disasters, epidemics, criminal activities against life, health and property [15].

Whereas by public order Franciszek Mroczko understands the actually existing system of social relations, regulated by a set of legal norms and other socially accepted standards, which guarantee undisturbed and conflict-free functioning of individuals in society [16]. According to him, public order defined in this way refers to all social relations that are covered by law and other norms that occur in the public space [17].

According to Franciszek Mroczko, the notions of security and public order should appear together (it must be noted here that in science there are also definitely different approaches [18]), because in some areas they overlap and are difficult to distinguish precisely. Both concepts are also inextricably linked to the institution of the state, its functioning, the law and its formation. However, these are not the same concepts, because their scopes are shifting, which is the effect of the emergence of new threats, alterations in legal norms, customs, morality, culture, ethics - the development of society [19].

Stanisław Pikulski also draws attention to the essence of public safety. In his opinion, public security is the supreme social value, which determines the safety of life, health and property of citizens and their relatives. He defines the concept of public safety as a certain desired state of affairs, guaranteeing undisturbed functioning of public facilities in the state and security of life, health and property of citizens. Stanisław Pikulski emphasises at the same time that it is the threatened entity, and not the source of danger, that determines allocation to this category. Public safety may therefore be disturbed by a person intentionally or unintentionally, and may bear the hallmarks of a crime or merely a misdemeanour. It may also be disrupted independently of human will, i.e. by forces of nature [20]. Public security may be perceived not only as a certain state of affairs but also as a process [21]. In this case, public security being an organised effort is a process of safeguarding people and their resources from unlawful actions violating these commodities [22].

Referring to public order, Stanisław Pikulski perceives it as a definite state of affairs, which is regulated by law, and which may be disturbed both by individuals and groups, and these disruptions may be of a misdemeanour or crime nature [23] .

According to Włodzimierz Fehler, public security is a component part of internal security. It is a state inside the State, through which the Government organisation is given conditions for the realisation of com- 
mon sub-unit objectives and effectively enforces duties, as well as protects the rights of individuals subordinate to that organism - the State. Here the author points to the unique protection by the state organisation of such rights as life, health and property. In this particular state entity there are both resources and mechanisms by means of which it is possible to respond effectively to situations, violating this condition [24].

Włodzimierz Fehler believes that both public safety and public order are components of domestic security. At the same time he points out that these terms are very often erroneously combined into one concept "public security and public order". According to the author an important argument for not merging these two notions into one - "public security and public order" is the fact that they use different legal and institutional instruments and ways of their application [25]. That is why he defines public order as "a desirable state of affairs, consistent with both legal and non-legal norms. It is a state in which the principles of social co-existence, high quality of public space and functioning of objects, devices and infrastructure intended for common use are respected, enabling safe functioning and realization of needs of individuals and social collectives" [26].

Stanislaw Pieprzny noted that the authors of the definition of public security, point out in those statements, that it is, regardless of the regime of the state and the degree of its development, always an element of the internal security of the country. Precisely the views of these authors, according to Stanislaw Pieprzny, have become an informal source of administrative law in determining the concept of public security. And the correct interpretation of the notion of public security by the bodies applying the law is essential, because the assessment of the existence of a possible threat to public security implies specific administrative sanctions and restrictions on the rights and freedoms of the individual, inter alia, through prohibitions, orders, administrative penalties [27].

Stanislaw Pieprzny considers that public order must be regarded as a positive state, which is formed by both legal and extra-legal norms (moral standards, principles of interpersonal coexistence), which are accepted and applied by the majority, ensuring proper co-existence and development of individuals and their communities. It is a state in which public entities responsible for the implementation of tasks in the field of public order actively participate. Stanisław Pieprzny points out that public order is to enable normal development of social life and to ensure compliance with regulations concerning behaviour in public places. The author also believes that it is impossible to exhaustively present all areas that are related to the provision of public order. He also draws attention to the fact that public law and order also change with the alteration of social relations - it is not a permanent category [28]
In turn, in the view of Władysław Kawka, public safety is a state in which the general public and their interests, as well as the state and its objectives, are protected against damage posed to them from any direction. Protection [29] of public security is thus the task of the state, which through legal norms determines what is consistent with security, and what constitutes a threat to safety and what measures to safeguard this security need to be taken [30].

Władysław Kawka defines public order as a set of legal and extra-legal norms (moral, ethical, custom, etc.), the observance of which is a prerequisite for normal co-existence of individuals in a state organisation. He points out that the formation of public order norms is influenced by political, religious, ethical moments, external customs, decency, etc. Thus, these are views which have grown up against the background of collective life, which presents itself differently depending on time, place and environment [31]. In the author's opinion, the concept of public order has left its mark on the transformations that collective life has undergone [32].

In turn, according to Jerzy Zaborowski, security is "a factual state within the state, which enables - without incurring damage from any source - the normal functioning of a government organisation and the realisation of its interests, the preservation of life, health and property of individuals living in this area, and the enjoyment by these individuals of rights and freedoms guaranteed by the constitution and other provisions of law" [33].

Jerzy Zaborowski perceives public order as "a factual state within the state, which gives the possibility for ordinary development of social life. An indispensable element for the realization of tasks aimed at achieving a certain goal by society is maintaining internal cohesiveness through the establishment of certain rules of conduct for its members. As a rule, these norms are regulated by customs, religious, moral norms, rules of social coexistence, but also in the case of state organisation by legal norms" [34].

In the words of Waldemar Kitler, public security is a process that encompasses various types of activities aimed at protecting the legal order in the State. Protection against actions that are prohibited and actions that are directed against public institutions and devices, life, health of people or public order, as well as against social standards and customs and interests of the state, which are secured by laws [35].

W. Kitler points out that public safety is often combined with public order - by using the term public security and public order. However, both public safety and public order are separate categories and could be combined into one category - public security. Although these terms are used together, only the provisions of criminal law make a separate reference to public order by listing offences against public order [36] 
W. Kitler assumed that public safety is superior to public order. And this results from the essence of public order, which is connected with observance of norms and maintenance of efficiency of public establishments [37]

The above are definitions and views on public safety and public order represented only by a few representatives and theorists in the field of security sciences. However, they give the possibility to make general conclusions about the nature of these concepts, pointing to the set of features that are characterisable, and thus to the essence of human being in the reality they create.

Firstly, public safety can be disrupted intentionally or without human will. Public order may be a legally ordered state of affairs that can be disturbed either by an individual or a group, and this disturbance may be in the nature of a misdemeanour or a crime. If it is disturbed by the will of man, by the perpetrators of criminal acts (misdemeanours or crimes). As a result, the offenders of these interferences are punished with penalties provided for specific prohibited acts, defined by law fine, reprimand, arrest, restriction of freedom or, in justified cases, the application to selected of them (offenders), measures of educational influence [38].

Secondly, we may state that both public safety and public order should be understood as a specific (desired) state (process) within the state, which enables undisturbed functioning of institutions, individuals, social groups in the state. At the same time this order is determined by law and other socially accepted norms, which include among others moral, cultural, ethical, religious norms or customs.

Thirdly, security and public order are changing, evaluating. The content of these concepts cannot be treated one-dimensionally or unambiguously, because they are not set in stone once and for all. The meaning of these concepts depends on many factors. They are influenced by determined and specific patterns of behaviour in a given community, prevailing conditions of life, and with it changing views and legal and non-legal norms [39].

Fourthly, the recipients of public safety and public order norms are primarily individuals, social groups and institutions within the state (although it is often institutions within the state that create these norms).

Fifthly, it has to be stressed that public order is inextricably linked to public security and that public safety should be regarded as an essential part of internal security.

\section{Summary}

This work can only be an introduction to further considerations and research on these issues. Which is all the more complicated and difficult because there are no unambiguous definitions concerning safety itself [40], including in the field of safety and public order, its hazards and their sources. There is also no uniform terminological and definitional nomenclature from other social sciences (e.g. law, sociology, psychology, political science and others) that would support and enable a thorough study of this issue.

To sum up, the nature of public security and order can be conceived as a process, which is sometimes disturbed intentionally or without human will. The level of security and public order, the framework of which has been established by the legislator, is protected by certain entities responsible for maintaining such state, and in the situation of its disturbance, these entities react in order to restore the initial state [41].

Mgr (MA) Anna Tyczkowska - Kowerczyk is a graduate of the University of Wrocław. Her interests include issues of state security, public safety and order, contemporary threats, local security and the use of modern technologies for security.

\section{Bibliography:}

1.https://encyklopedia.pwn.pl/haslo/natura; 40 09276.html, 01.02.2021.

2. https://sjp.pwn.pl/, 01.02.2021.

3. B. Kogut, P. Lubiewski, Management and coordination of rescue activities, Вісник Львівського державного університету безпеки життєдіяльності, Nr 17, Львів 2018, pp. 68-73.

4. More, A. Czupryński, B. Wiśniewski, J. Zboina, Nauki o bezpieczeństwie. Wybrane problemy badań, Centrum Naukowo-Badawcze Ochrony Przeciwpożarowej im. Józefa Tuliszkowskiego Państwowy Instytut Badawczy, Józefów 2017.

5. More, B. Wiśniewski (red. nauk.), Bezpieczeństwo $w$ teorii $i$ badaniach naukowych, WSPol, Szczytno 2011.

6. More, K. Jałoszyński, B. Wiśniewski, T. Wojtuszek (red. nauk.), Wspótczesne postrzeganie bezpieczeństwa, WSA, Bielsko-Biała 2007.

7. B. Wiśniewski, R. Kowalski, J. Kozioł, M Szyłkowska, Bezpieczeństwo procesów decyzyjnych, TUM, Wrocław 2018, p. 5.

8. B. Wiśniewski, Praktyczne aspekty badań bezpieczeństwa, Difin, Warszawa 2020, pp. 15-28.

9. Porzadek publiczny a bezpieczeństwo publiczne, https://www.lex-pol.pl/porzadek-publiczny-abezpieczenstwo-publiczne/, 21.12.2020 r.

10. R. Gwardyński, Wybrane problemy działań prewencyjnych Policji, „Zeszyty Naukowe SGSP” Nr 74/2/2020, Szkoła Główna Służby Pożarniczej, Warszawa 2020 , p. 302.

11. More, B. Wiśniewski, Z. Piątek (red. nauk.), Współczesny wymiar funkcjonowania Policji, AON, Warszawa 2009.

12. https://sjp.pwn.pl/, 01.02.2021.

13. More, R. Jakubczak, B. Wiśniewski (red. nauk.), Wyzwania, szanse, zagrożenia i ryzyko dla bezpieczeństwa narodowego $R P$ o charakterze wewnętrznym, WSPol, Szczytno 2016. 
14. More, B. Kaczmarczyk, B. Wiśniewski, R. Gwardyński, Security of an individual, Zeszyty Naukowe Państwowej Wyższej Szkoły Zawodowej im. Witelona w Legnicy Nr 3 (28), pp. 67 - 78.

15. F. Mroczko, Problemy bezpieczeństwa $i$ porzadku publicznego, Zeszyty Naukowe WWSZIP Refleksje Gospodarcze nr 14 (1)2010, Wałbrzych 2010, pp. 35-36.

16. Ibidem, pp. 35-36.

17. Ibidem.

18. More, R. Gwardyński, Security and Public Security, [in:] Internal Security and Public Security, Schriften zu Mittel- und Osteuropa in der Europeischen Integration, Band 25, (red.) B. Wiśniewski, G.G. Sander, P. Kobes, Verlag Dr. Kovač, Hamburg 2020.

19. F. Mroczko, Problemy bezpieczeństwa..., op. cit., p. 36.

20. W. Bednarek, S. Pikulski (red.), Prawne $i$ administracyjne aspekty bezpieczeństwa osób $i$ porzadku publicznego w okresie transformacji ustrojowo-gospodarczej, Wydawnictwo Uniwersytetu Warmińsko-Mazurskiego, Olsztyn 2000, p. 101.

21. R. Gwardyński, Safety in Praxeological Aproach, [in:] Security - Threats, Law and Organization, Schriften zu Mittel- und Osteuropa in der Europeischen Integration, Band 24, (red.) B. Wiśniewski, G.G. Sander, P. Kobes, Verlag Dr. Kovač, Hamburg 2019, p. 11.

22. R. Gwardyński, O mierze sprawności działania policji, "Zeszyty Naukowe Państwowej Wyższej Szkoły Zawodowej im. Witelona w Legnicy", nr 36(3)/2020, p. 47.

23. W. Bednarek, S. Pikulski (red.), Prawne $i$ administracyjne..., op. cit., p. 101.

24. W. Fehler, O pojęciu polityki wewnętrznej państwa, Studia Prawnoustrojowe nr 23, Wydawnictwo Uniwersytetu Warmińsko-Mazurskiego w Olsztynie, Olsztyn 2014, pp. 206-207.

25. Ibidem, p. 206.

26. Ibidem, p. 207.

27. S. Pieprzny, Ochrona bezpieczeństwa $i$ porzadku publicznego $w$ prawie administracyjnym, Wydawnictwo Uniwersytetu Rzeszowskiego, Rzeszów 2007, pp. 31-39.
28. Ibidem, pp. 14-15.

29. P. Lubiewski, R. Gwardyński, Ochrona zabytków przed zagrożeniami terrorystycznymi, kryminalnymi, militarnymi $i$ pozamilitarnymi, Katedra Bezpieczeństwa Społecznego Instytutu Bezpieczeństwa i Edukacji Obywatelskiej Wydziału Pedagogicznego Uniwersytetu Pedagogicznego w Krakowie, Kraków 2018, p. 7.

30. W. Kawka, Policja w ujęciu historycznym $i$ współczesnym, wyd. z zasiłku Zakładu Administracji i Prawa Administracyjnego U.S.B., Drukarnia "Zorza", Wilno 1939, pp. 3-5.

31. W. Kawka, op. cit., pp. 46, 67, 69, 73.

32. S. Pieprzny, Administracja bezpieczeństwa ..., op. cit., pp. 14-15.

33. J. Zaborowski, Prawne środki zapewnienia bezpieczeństwa i porzadku publicznego, Departament Szkolenia i Doskonalenia Zawodowego MSW, Warszawa 1977, p. 11.

34. Ibidem, pp,11-12.

35. W. Kitler, Organizacja bezpieczeństwa narodowego $R P \quad w$ kontekście ochrony tadu wewnętrznego w państwie, Zeszyty Naukowe AON nr 4(93) 2013, Warszawa 2013, p.233.

36. Ibidem, p. 234.

37. Ibidem.

38. R. Gwardyński, Możliwości doskonalenia działań prewencyjnych Policji, AWL, Wrocław 2019, p. 79.

39. M. Kotulski, Samorzad terytorialny wobec zapewnienia porządku $i$ bezpieczeństwa publicznego, [in:] Bednarek W., Pikulski S. (red.), Prawne i administracyjne aspekty bezpieczeństwa osób i porzadku publicznego $w$ okresie transformacji ustrojowo-gospodarczej, UWM, Olsztyn 2000, p.311.

40. More, A. Czupryński, B. Wiśniewski, J. Zboina (red. nauk.), Bezpieczeństwo. Teoria - Badania - Praktyka, CNBOP - PIB, Józefów 2015.

41. A. Tyczkowska-Kowerczyk, Funkcjonowanie straży gminnych (miejskich) w kontekście bezpieczeństwa i porzadku publicznego spoleczności lokalnej, Zeszyty Naukowe SGSP nr 76/4/2020, Warszawa 2020, p.138.

\section{* Оглядова стаття}

Стаття надійшла до редакції 01.12.2021. 